\title{
Investigation of the Germination of Barley and Wheat Grains with a Design of Experiments for the Production of Hydrolases
}

\author{
Bertolt Kranz $z^{\S}$ Milena Koch§, Matthias Schapfl§ and Lutz Fischer* \\ University of Hohenheim, Institute of Food Science and Biotechnology, \\ Department of Biotechnology and Enzyme Science, Garbenstr. 25, DE-70599 Stuttgart, Germany
}

Received: May 8, 2014

Accepted: March 9, 2015

\begin{abstract}
Summary
The production of hydrolases from cereals has been examined in order to investigate food-derived enzymes as an alternative source to microbial enzymes for the use in food processes. For that, the influence of temperature on the pretreatment, imbibition and germination of barley and wheat grains was determined by measuring the $\beta$-glucosidase, $\beta$-galactosidase and lipase activities using a design of experiments. The evaluation of the statistical model showed an increase of the $\beta$-glucosidase activity with low imbibition and low germination temperature for barley grains and low imbibition and high germination temperature for wheat grains. The maximum $\beta$-glucosidase activity in wheat extracts was $(585 \pm 151)$ nkat per $g$ of dry mass $(\mathrm{dm})$, while in barley extracts it was $(109 \pm 15)$ nkat per $\mathrm{g}$ of $\mathrm{dm}$. The maximum $\beta$-galactosidase activities in barley and wheat extracts were $(34 \pm 12)$ and $(63 \pm 23)$ nkat per $g$ of $d m$, respectively. The maximum lipase activities of $(6.7 \pm 0.1)$ and $(4.6 \pm 4.4)$ nkat per $g$ of $\mathrm{dm}$ in barley and wheat extracts, respectively, were rather low compared to the glycosidase activities. The extracts were also tested for other hydrolase activities (e.g. peptidase and $\alpha$-amylase activities). The insights obtained enable the basis for the potential use of cereal hydrolases in food processing, which might be attractive to consumers.
\end{abstract}

Key words: cereal grain, glucosidase, galactosidase, design of experiments, germination, hydrolase production

\section{Introduction}

Many enzymes from different classes used for food processing (1-5) originate from genetically modified microorganisms (6). People in Finland, Italy and Germany show the most positive attitude towards the use of endogenic enzymes from plants (without genetic modification) and most negative towards the use of genetically modified enzymes, regardless of whether they are of microbial or plant origin, as shown by a study about consumers' attitudes to enzymes in food production (7). This attitude is driven by sociopolitical viewpoints, and even a price reduction of $25 \%$ does not seem to change their buying intention. In a study about the degradation of gliadin pep- tides with peptidases from germinated wheat, barley and rye grains, the authors stated that peptidases derived from germinated grains have a higher acceptance by coeliac patients (8). Hence, it seems that non-genetically modified enzymes and enzymes from natural origins (e.g. plants) and not from microorganisms are of high interest for certain consumers. Additionally, the grain-associated peptidases are more suitable for the hydrolysis of some food ingredients, e.g. gluten (9).

Most of the enzymes in cereal grains are hydrolytic enzymes, e.g. $\alpha$-amylases (EC 3.2.1.1), cellulases (EC 3.2. 1.4), endoxylanases (EC 3.2.1.8), $\alpha$-L-arabinofuranosidases (EC 3.2.1.55), peptidases (EC 3.4.X.X) and lipases (EC

*Corresponding author: Phone: +49 7114592 3018; Fax: +49 7114592 4267; E-mail: lutz.fischer@uni-hohenheim.de

\$These authors contributed equally to this work 
3.1.1.3) (10). Many hydrolases are used for industrial processes. $\beta$-Glucosidases (EC 3.2.1.21), for example, are used for the degradation of cellobiose to glucose (11), which is important for the fabrication of glucose from cellulose. $\beta$ -Galactosidase (EC 3.2.1.23, lactase), e.g. from Kluyveromyces lactis (12) or Candida pseudotropicalis (13), is used for the conversion of lactose to glucose and galactose in milk products. $\alpha$-Amylases (10) and endoxylanases (14) are used for the improvement of baking process; some of these enzyme preparations are grain-associated. Grain-associated hydrolases from barley increase their activity manyfold during the germination of the grains (15). Thus, it is important to use germinated grains for the production of hydrolases in order to get a sufficient yield. The yields also depend on the type of cereal and the used cultivar.

Enzymes from germinating seeds have been used for food processing for several years (16). However, $\beta$-glucosidase and $\beta$-galactosidase, and systematic germination with a design of experiments in order to extend the yield were not the focus of these research activities.

In this study, the activities of selected hydrolases (glycosidases, peptidases, esterases and lipases) of the extracts from germinating barley and wheat grains are determined. Consequently, the grains were imbibed and germinated according to the beer-brewing process, as has been done in several studies previously (17-19). These conditions were varied and three hydrolase activities ( $\beta$-glucosidase, $\beta$-galactosidase and lipase) were investigated with a design of experiments. The aim of this study is the examination of the total yields of hydrolases from grains of barley and wheat for food processes.

\section{Materials and Methods}

\section{Materials}

Barley (Hordeum vulgare L. Grace) and wheat (Triticum aestivum L. Akteur) grown and harvested in Germany in 2011 were kindly provided by Dr. J. Ackermann \& Co. (Irlbach, Germany) and Deutsche Saatgutveredelung AG (Lippstadt, Germany), respectively. Dry grains were stored in the dark at $(20 \pm 4)^{\circ} \mathrm{C}$.

The following substrates, $p$-nitrophenyl- $\alpha$-L-arabinofuranoside ( $p$ NPAra), $p$ NP- $\beta$-D-cellobioside ( $p$ NPCel), $p$ NP- $\beta$-D-galactopyranoside ( $p \mathrm{NPGal}), p \mathrm{NP}-\beta$-D-glucopyranoside $(p N P G l c), p N P-\beta$-D-xylanopyranoside ( $p$ NPXyl), azo-arabinoxylan (from wheat), azo-casein (bovine), azo-galactomannan (from carob), azo-glucan (from barley), 4-methylumbelliferyl acetate (4-MUA) and 4-methylumbelliferyl butyrate (4-MUB) were purchased from Sigma-Aldrich (Taufkirchen, Germany). 4-Methylumbelliferyl laurate (4-MUL) and 4-methylumbelliferyl caprylate (4-MUC) were bought from Santa Cruz Biotechnology (Dallas, TX, USA). Carboxymethylcellulose $(\mathrm{CMC})$ and polygalacturonic acid sodium salt (PGA) were purchased from Serva (Heidelberg, Germany). Soluble starch and xylan from oat spelt were obtained from Merck (Darmstadt, Germany) and Roth (Karlsruhe, Germany), respectively. The chromogenic peptides, H-Ala-Ala-Pro-Leu- $p$ NA, H-Ala-Phe- $p$ NA, Z-Ala-Ala-Leu- $p$ NA, Pyr-Phe-Leu- $p$ NA, and Z-Gly-Gly-Leu$-p$ NA were bought from Bachem (Bubendorf, Switzerland). Other chemicals were of analytical grade and purchased from Sigma-Aldrich. All solutions were made with ultrapure water.

If not otherwise described, each experiment was carried out independently (on different days) in duplicate and each sampling was also carried out in duplicate. For each sampling, $2.5 \mathrm{~g}$ were taken, which correlates to at least 50 grains of wheat or 60 grains of barley. A negative control (hydrolases deactivated at $90{ }^{\circ} \mathrm{C}$ for $15 \mathrm{~min}$ ) was performed for all experiments.

The limit of detection (LOD) and the limit of quantification (LOQ) are defined as the sixfold and ninefold signal-to-noise ratio, respectively.

\section{Growth stage scale}

The phenological changes of barley and wheat grains were characterised as published previously (20). The following modifications of the growth stages were used: $08=$ leaf just at coleoptile tip, $09=$ first leaf penetrates coleoptile, and 10=first leaf through coleoptile.

\section{Cereal processing for preliminary experiments}

Barley and wheat grains were allowed to imbibe tap water up to $28 \mathrm{~h}$ at $(20 \pm 2)^{\circ} \mathrm{C}$ and samples were taken regularly to determine the water content. Germination was carried out at $20^{\circ} \mathrm{C}$ in the absence of light without moisturising after imbibition (for $16 \mathrm{~h}$ ) and, in an alternative experiment, with watering twice a day with tap water for $30 \mathrm{~s}$. Germination was carried out at 25 and $30{ }^{\circ} \mathrm{C}$ in the absence of light, watering twice a day with tap water for $30 \mathrm{~s}$. The effect of watering on $\beta$-glucosidase activity was measured as described below.

\section{Cereal processing for the main experiments and the experimental design}

The influence of temperature on the three treatment steps: pretreatment, imbibition and germination of barley and wheat grains was investigated. The cereals were pretreated for $48 \mathrm{~h}$ and imbibed for $16 \mathrm{~h}$. After removal of the liquid, germination was carried out on a tray (the tray was filled with $500 \mathrm{~mL}$ of distilled water without contact with the grains) in the absence of light with moisturising once a day by immersing the grains for $5 \mathrm{~min}$. All watering steps were performed using a mineral solution $\left(7 \cdot 10^{-5}\right.$ $\mathrm{mM} \mathrm{FeCl} 2 \cdot 4 \mathrm{H}_{2} \mathrm{O}, 1.8 \cdot 10^{-4} \mathrm{mM} \mathrm{ZnCl}_{2}, 1.8 \cdot 10^{-4} \mathrm{mM} \mathrm{MnCl}_{2}$. $\mathrm{H}_{2} \mathrm{O}, 7 \cdot 10^{-5} \mathrm{mM} \mathrm{H}_{3} \mathrm{BO}_{3}, 1.25 \cdot 10^{-5} \mathrm{mM} \mathrm{CuCl}_{2} \cdot 2 \mathrm{H}_{2} \mathrm{O}, 7 \cdot 10^{-3}$ $\mathrm{mM} \mathrm{CaCl} 2 \cdot 2 \mathrm{H}_{2} \mathrm{O}, 7 \cdot 10^{-3} \mathrm{mM} \mathrm{NaCl}, 1.4 \cdot 10^{-2} \mathrm{mM} \mathrm{MgCl}{ }_{2}$ 4.3 $10^{-2} \mathrm{mM} \mathrm{KH}_{2} \mathrm{PO}_{4}$ and $4.3 \cdot 10^{-2} \mathrm{mM} \mathrm{K}_{2} \mathrm{HPO}_{4}$ ). The tray contained $350 \mathrm{~g}$ of grains (average specific mass of wheat grain was $0.05 \mathrm{~g}$ and of barley grain $0.04 \mathrm{~g}$ ), which formed a monolayer.

Germination experiments were carried out until the grains reached growth stage 10 (see above). Samples were taken after each treatment step and every or every other day (when germinated at $6{ }^{\circ} \mathrm{C}$ ) during germination, and stored at $-18^{\circ} \mathrm{C}$ until further analysis.

Three factors were considered for the screening test: the temperature during pretreatment, imbibition and germination, respectively. The temperature was varied in each of the three treatment steps. A $2^{3}$ factorial design was chosen with a total of 19 runs consisting of eight corner 
points in duplicate and three centre-point replicates, thus, nine different experiments (Table 1).

Table 1. Temperatures of the nine experiments of the two-level factorial design for barley and wheat

\begin{tabular}{cccc}
\hline \multirow{2}{*}{ No. } & \multicolumn{3}{c}{ Temperature $/{ }^{\circ} \mathrm{C}$} \\
\cline { 2 - 4 } & Pretreatment & Imbibition & Germination \\
\hline $1^{\text {a }}$ & -18 & 37 & 6 \\
$2^{\text {a }}$ & 50 & 37 & 6 \\
$3^{\text {a }}$ & -18 & 4 & 6 \\
$4^{\text {a }}$ & 50 & 4 & 6 \\
$5^{\text {b }}$ & 16 & 20 & 16 \\
$6^{\text {a }}$ & -18 & 37 & 20 \\
$7^{\text {a }}$ & 50 & 37 & 20 \\
$8^{\text {a }}$ & -18 & 4 & 20 \\
$9^{\text {a }}$ & 50 & 4 & 20 \\
\hline
\end{tabular}

${ }^{\mathrm{a}}$ corner point, ${ }^{\mathrm{b}}$ centre point

The pretreatment temperature was in the range from frozen soil $\left(-18{ }^{\circ} \mathrm{C}\right)$ to an overheated depot $\left(50^{\circ} \mathrm{C}\right)$, simulating the seeding or storage of the grain. The imbibition and germination temperatures ranged from a cold room $\left(4\right.$ to $\left.6{ }^{\circ} \mathrm{C}\right)$ to a depot in summer $\left(37^{\circ} \mathrm{C}\right)$. Preliminary experiments (see below) showed that a maximum of $20^{\circ} \mathrm{C}$ for germination is imperative for avoiding microbial growth.

Statistical analysis (ANOVA) of the observations was performed with the software Design-Expert v. 8 (StatEase, Inc., Minneapolis, MN, USA). Differences at $\mathrm{p} \leq 0.05$ were considered significant. A calculation was made for the prediction of the influence of temperature on the $\beta$-glucosidase activity in the examined range. The priority of the target dimension was the maximum $\beta$-glucosidase activity.

\section{Enzyme extraction}

The frozen samples $(2.5 \mathrm{~g})$ were homogenised after the addition of $10 \mathrm{~mL}$ of $\mathrm{H}_{2} \mathrm{O}$ using Ultra-Turrax (IKA, Staufen, Germany, idle speed: $13000 \mathrm{rpm}$ ) for cell disruption at $0-4{ }^{\circ} \mathrm{C}$ for 4 or $6 \mathrm{~min}$ (wheat and barley grains, respectively). The homogenate was centrifuged (8 $000 \times g$ at $4{ }^{\circ} \mathrm{C}$ for $15 \mathrm{~min}$ ) to obtain the enzyme extract (supernatant), which was immediately used for the determination of dry mass and enzyme activities.

\section{Determination of dry mass}

A volume of $2 \mathrm{~mL}$ was removed from the supernatant of the homogenates and dried at $100{ }^{\circ} \mathrm{C}$ for $48 \mathrm{~h}$ for the determination of dry mass (in triplicate) of the extracts. The dry mass of the grains was determined by weighing before and after drying at $100{ }^{\circ} \mathrm{C}$ for $48 \mathrm{~h}$ (at least 50 grains, in triplicate). The dry mass of the grains was constant over the germination time. The water to total mass ratio during germination was always $\zeta=0.12$ (standard deviation $<5 \%$ ). The total mass (including moisture) of the grains was determined for each process step (pretreat- ment, imbibition and germination), as well as for each sample, and was expressed in $\mathrm{kg}$ of grain.

\section{Determination of hydrolytic activities}

Measurements of the enzyme extracts were performed in triplicate using $0.1 \mathrm{M}$ sodium phosphate buffer $(\mathrm{pH}=6.0)$ for barley and $33 \mathrm{mM}$ sodium phosphate buffer $(\mathrm{pH}=6.3)$ for wheat extract.

The determination of the activity of exoglycosidases, namely $\beta$-D-galactosidase (EC 3.2.1.23; $40 \mathrm{mM} p \mathrm{NPGal}$ ), $\beta$-D-glucosidase (EC 3.2.1.21; $40 \mathrm{mM} p \mathrm{NPGl}$ ), $\beta$-D-xylosidase (EC 3.2.1.37; $5 \mathrm{mM} p \mathrm{NPX}$ yl), $\alpha$-L-arabinofuranosidase (EC 3.2.1.55; $15 \mathrm{mM} p$ NPAra with $50 \%$ methanol) and cellobiosidase (EC 3.2.1.91; $15 \mathrm{mM} p$ NPCel with $20 \%$ methanol) was carried out with $p$-nitrophenylglycosides in water. The buffer $(100 \mu \mathrm{L})$ was incubated with substrate solution $(120 \mu \mathrm{L})$ at $37^{\circ} \mathrm{C}$. The reaction was started by the addition of $20 \mu \mathrm{L}$ of enzyme extract. The absorbance change was measured at $405 \mathrm{~nm}$ (5 min, intervals: $20 \mathrm{~s}$ ). One katal of activity is defined as the amount of enzyme that releases one mole of $p$-nitrophenol per second.

The activities of $\alpha$-amylase (EC 3.2.1.1), cellulase (EC 3.2.1.4), endoxylanase (EC 3.2.1.8) and galacturonase (EC 3.2.1.15) were measured according to the modified Somogyi-Nelson method $(21,22)$ with starch, carboxymethylcellulose, xylan and sodium polygalacturanate as substrates, respectively. The assays were performed as a multipoint reaction (five points) from 1 to $12 \mathrm{~min}$. One katal of activity is defined as the amount of enzyme that releases one mole of monosaccharide (glucose, xylose or galacturonate) per second.

The activity of endoglycosidases was analysed using the azo-dyed substrates azo-arabinoxylan $(1.0 \mathrm{~g} / \mathrm{L}$, powder), azo-galactomannan (0.2 g/L, powder) and azo-glucan $(1.0 \mathrm{~g} / \mathrm{L}$, liquid). Each assay was carried out as a multipoint reaction (six points) at $37{ }^{\circ} \mathrm{C}$ and the absorbance change of the supernatant was measured at $595 \mathrm{~nm}$. All substrates and measurements were carried out according to the manufacturer's instructions (Megazyme Ltd., Bray, Ireland). The absorption change was defined as the increase of the absorption signal at $595 \mathrm{~nm}$ per second per dry mass.

Endopeptidase activity was measured with the substrate azo-casein (23). The enzyme extract $(100 \mu \mathrm{L})$ and buffer $(115 \mu \mathrm{L})$ were preincubated at $37^{\circ} \mathrm{C}$ for $5 \mathrm{~min}$. The reaction was started by the addition of $60 \mu \mathrm{L}$ of azo-casein $(25 \mathrm{~g} / \mathrm{L})$ in buffer, stopped after $10 \mathrm{~min}$ with $25 \mu \mathrm{L}$ of $2 \mathrm{M}$ trichloroacetic acid and centrifuged at $13000 \times g$ for $5 \mathrm{~min}$. The supernatant $(188 \mu \mathrm{L})$ was added to $1 \mathrm{M} \mathrm{NaOH}(62$ $\mu \mathrm{L})$ and the absorption was measured at $450 \mathrm{~nm}$. The absorption change was defined as the increase of the absorption signal at $450 \mathrm{~nm}$ per second and per dry mass (kg of grain).

For the determination of the activity towards chromogenic peptides, $177 \mu \mathrm{L}$ of the buffer were preincubated with $50 \mu \mathrm{L}$ of enzyme extract at $37^{\circ} \mathrm{C}$. The reaction was started by the addition of $13 \mu \mathrm{L}$ of substrate solution (10 $\mathrm{mg} / \mathrm{mL}$ of chromogenic peptide dissolved in $\mathrm{N}, \mathrm{N}$-dimethylformamide) of $\mathrm{H}$-Ala-Ala-Pro-Leu- $p \mathrm{NA} \cdot \mathrm{HCl}, \mathrm{H}-\mathrm{Ala}-$ -Phe- $p$ NA.HCl, Z-Ala-Ala-Leu- $p$ NA, Pyr-Phe-Leu- $p$ NA or Z-Gly-Gly-Leu- $p$ NA. The absorption change was mea- 
sured at $405 \mathrm{~nm}$ ( $5 \mathrm{~min}$, intervals: $20 \mathrm{~s}$ ). One katal of activity is defined as the amount of enzyme that releases one mole of $p$-nitroaniline per second.

Lipase and esterase activities were analysed with 4-methylumbelliferone-substituted substrates (4-MUA, 4-MUB, 4-MUC and 4-MUL). The enzyme extract $(50 \mu \mathrm{L})$ was preincubated with $120 \mu \mathrm{L}$ of buffer and $10 \mu \mathrm{L}$ of Triton $\mathrm{X}-100$ in water $(\varphi=0.1)$ at $37^{\circ} \mathrm{C}$ for $5 \mathrm{~min}$. The reaction was started by the addition of $20 \mu \mathrm{L}$ of substrate solution (5 mM 4-MUA, $10 \mathrm{mM}$ 4-MUB, $10 \mathrm{mM}$ 4-MUC and 10 $\mathrm{mM}$ 4-MUL in isopropyl alcohol, respectively). The fluorescence was measured for $5 \mathrm{~min}$ (intervals: $10 \mathrm{~s}$, $\lambda=355 / 460 \mathrm{~nm}$ ). One katal of activity is defined as the amount of enzyme that releases one mole of 4-methylumbelliferone per second.

\section{Results}

\section{Preliminary experiments}

First it was investigated which parameters (such as water content and temperature) influence the production of hydrolytic enzymes during germination (preliminary experiments). The water content in both barley and wheat grains reached a plateau of 50 and $40 \%$, respectively, after
$16 \mathrm{~h}$ of imbibition (data not shown). The experiments showed that the daily rinsing of the cereal grains resulted in a twofold higher specific activity of $\beta$-glucosidases (a marker enzyme in this study) per grain dry mass during the germination process. Germination temperature higher than $20^{\circ} \mathrm{C}\left(25\right.$ and $\left.30^{\circ} \mathrm{C}\right)$ did not lead to higher enzyme activities (data not shown). In summary, $16 \mathrm{~h}$ of imbibition and germination at no more than $20^{\circ} \mathrm{C}$ were used in all experiments.

\section{Screening for hydrolytic enzymes in barley and wheat grains}

The enzyme extracts from barley and wheat were tested for different enzyme activities (Table 2). Different temperatures were chosen for these screening experiments in order to cover a broad temperature range. A straight comparison of the results was done with the afterwards obtained main results (see Table 3).

By far the most abundant enzyme activity present in both barley and wheat extracts was that of $\alpha$-amylase, with an almost twelvefold higher $\alpha$-amylase activity in the germinated barley extract (roughly $118000 \mu$ kat per $\mathrm{kg}$ of grain) than in the wheat extract (about $10000 \mu \mathrm{kat}$ per $\mathrm{kg}$ of grain). Other endoglycosidase activities were determined with azo-dyed substrates. The barley extracts

Table 2. Hydrolase activity found in the extracts from barley (pretreatment: $37^{\circ} \mathrm{C}$, imbibition: $4{ }^{\circ} \mathrm{C}$, germination for 12 days: $7{ }^{\circ} \mathrm{C}$ ) and wheat (pretreatment: $-18{ }^{\circ} \mathrm{C}$, imbibition: $25^{\circ} \mathrm{C}$, germination for five days: $20^{\circ} \mathrm{C}$ )

\begin{tabular}{|c|c|c|c|}
\hline \multirow{2}{*}{ Hydrolase } & \multirow{2}{*}{ Substrate } & \multicolumn{2}{|c|}{ Enzyme activity/( $\mu$ kat per kg of grain) } \\
\hline & & Barley & Wheat \\
\hline$\alpha$-arabinofuranosidase & $p$ NPAra & $2.2 \pm 0.4$ & $1.6 \pm 0.1$ \\
\hline$\beta$-cellobiosidase & $p$ NPCel & $0.8 \pm 0.0$ & $6.9 \pm 0.02$ \\
\hline$\beta$-galactosidase & $p$ NPGal & $35 \pm 7.3$ & $48.6 \pm 0.7$ \\
\hline$\beta$-glucosidase & $p$ NPGlc & $102 \pm 11$ & $437 \pm 3$ \\
\hline$\beta$-xylosidase & $p \mathrm{NPXyl}$ & $1.6 \pm 0.0$ & $9.9 \pm 0.13$ \\
\hline$\alpha$-amylase & starch & $118273 \pm 8169$ & $9665 \pm 22$ \\
\hline cellulase & carboxymethylcellulose & $<$ LOQ & $<$ LOQ \\
\hline galacturonase & sodiumpolygalacturanate & $<\mathrm{LOQ}$ & $<$ LOQ \\
\hline xylanase & xylan & $<\mathrm{LOQ}$ & $<\mathrm{LOQ}$ \\
\hline exopeptidase & Z-Ala-Ala-Leu- $p$ NA & $0.36 \pm 0.29$ & n.d. \\
\hline exopeptidase & Pyr-Phe-Leu- $p$ NA & $0.27 \pm 0.25$ & $<\mathrm{LOQ}$ \\
\hline exopeptidase & H-Ala-Ala-Pro-Leu- $p$ NA & $0.27 \pm 0.02$ & $<$ LOQ \\
\hline exopeptidase & $\mathrm{H}$-Ala-Phe- $p \mathrm{NA} \cdot \mathrm{HCl}$ & $0.18 \pm 0.00$ & $<\mathrm{LOQ}$ \\
\hline esterase & 4-MUA & $2.2 \pm 0.1$ & n.d. \\
\hline esterase & 4-MUB & $1.2 \pm 0.1$ & n.d. \\
\hline esterase & 4-MUC & $0.9 \pm 0.1$ & n.d. \\
\hline \multirow[t]{2}{*}{ lipase } & 4-MUL & $6.0 \pm 0.1$ & $0.23 \pm 0.01$ \\
\hline & & \multicolumn{2}{|c|}{ Absorption change } \\
\hline endopeptidase & azo-casein & $1.84 \pm 0.18$ & $0.56 \pm 0.01$ \\
\hline endoxylanase & azo-arabinoxylan & $0.16 \pm 0.02$ & $0.69 \pm 0.09$ \\
\hline endoglucanase & azo-glucane & $1.16 \pm 0.02$ & $<$ LOQ \\
\hline galactomannase & azo-galactomannane & $0.52 \pm 0.07$ & $<\mathrm{LOQ}$ \\
\hline
\end{tabular}

Results represent the mean value \pm standard deviation of two independent measurements

$\mathrm{LOQ}=$ limit of quantification, n.d.=not determined. Absorption change is defined as the increase of $A$ at $595 \mathrm{~nm}$ (for azo-casein at 450 $\mathrm{nm}$ ) per s per $1 \mathrm{~kg}$ of grain dry mass 
Table 3. Hydrolase activities ( $\beta$-glucosidase, $\beta$-galactosidase and lipase) in barley and wheat from the nine experiments of the two-level factorial design

\begin{tabular}{|c|c|c|c|c|c|c|}
\hline \multirow{4}{*}{ No.* } & \multicolumn{6}{|c|}{ Enzyme activity/(nkat per $\mathrm{g}$ of $\mathrm{dm}$ ) } \\
\hline & \multicolumn{3}{|c|}{ Barley } & \multicolumn{3}{|c|}{ Wheat } \\
\hline & $\beta$-glucosidase & $\beta$-galactosidase & lipase & $\beta$-glucosidase & $\beta$-galactosidase & lipase \\
\hline & $p$ NPGlc & $p$ NPGal & 4-MUL & $p$ NPGlc & $p$ NPGal & 4-MUL \\
\hline 1 & $60 \pm 3$ & $22 \pm 0.3$ & $2.6 \pm 1.3$ & $138 \pm 3$ & $13.0 \pm 0.2$ & $4.6 \pm 4.4$ \\
\hline 2 & $65 \pm 5$ & $22 \pm 1.3$ & $4.3 \pm 1.6$ & $78 \pm 3$ & $7.1 \pm 0.3$ & $0.8 \pm 0.7$ \\
\hline 3 & $96 \pm 5$ & $24 \pm 0.3$ & $2.3 \pm 1.0$ & $241 \pm 37$ & $27 \pm 1.0$ & $2.5^{* *}$ \\
\hline 4 & $109 \pm 15$ & $27 \pm 4$ & $3.1 \pm 1.9$ & $121 \pm 27$ & $11 \pm 2$ & $1.1 \pm 1.0$ \\
\hline 5 & $105 \pm 8$ & $27 \pm 0.8$ & $6.7 \pm 0.1$ & $506 \pm 29$ & $58 \pm 9$ & $0.5 \pm 0.2$ \\
\hline 6 & $90 \pm 24$ & $34 \pm 12$ & $3.3 \pm 0.6$ & $585 \pm 151$ & $59 \pm 10$ & $<\mathrm{LOQ}$ \\
\hline 7 & $79 \pm 7$ & $25 \pm 3$ & $2.7 \pm 0.5$ & $448 \pm 130$ & $46 \pm 12$ & $<\mathrm{LOQ}$ \\
\hline 8 & $102 \pm 11$ & $34 \pm 8$ & $2.8 \pm 0.1$ & $535 \pm 224$ & $63 \pm 26$ & $<\mathrm{LOQ}$ \\
\hline 9 & $103 \pm 15$ & $24 \pm 3$ & $2.6 \pm 0.1$ & $574 \pm 265$ & $53 \pm 13$ & $<\mathrm{LOQ}$ \\
\hline
\end{tabular}

Results represent the mean value \pm standard deviation of two independent measurements

*see Table 1 for processing conditions of the respective experiment number, ${ }^{* *}$ single measurement; LOQ=limit of quantification, dm=dry mass

showed higher endoglucanase (1.16) and galactomannase (0.52) absorption change than wheat extracts, in which both absorption changes were smaller than the LOQ.

The $\beta$-cellobiosidase (EC 3.2.1.91) activity was eightfold higher in the wheat (7.0 $\mu$ kat per $\mathrm{kg}$ of grain) than in the barley extracts $(0.8 \mu \mathrm{kat}$ per $\mathrm{kg}$ of grain). The other exoglycosidase activities, namely $\beta$-galactosidase, $\beta$-glucosidase and $\beta$-xylosidase, were also up to sixfold higher in the wheat than in the barley extracts. The $\alpha$-arabinofuranosidase activity was slightly higher in barley (2.2 $\mu$ kat per $\mathrm{kg}$ of grain) than in wheat extracts $(1.6 \mu \mathrm{kat}$ per $\mathrm{kg}$ of grain).

The barley extract exhibits a higher endopeptidase (1.84) absorption change than the wheat extract (0.56). Exopeptidase activities of the chromogenic peptides used in this study were lower, ranging between 0.18 and 0.36 $\mu \mathrm{kat}$ per $\mathrm{kg}$ of grain in the barley extracts, and they were lower than the LOQ in the wheat extracts.

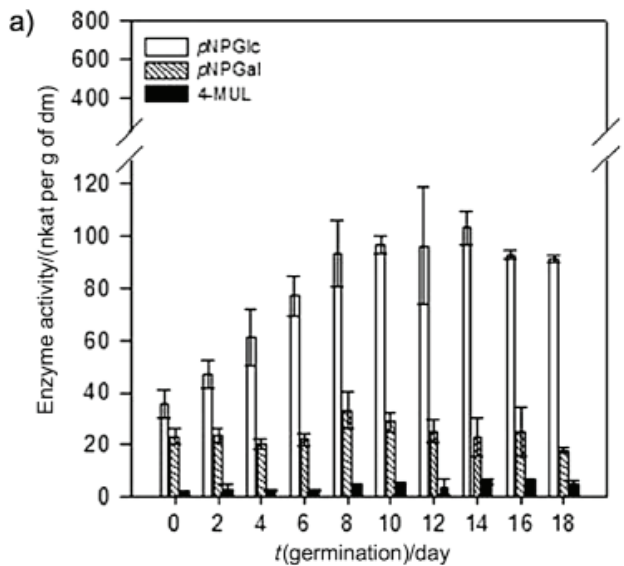

Lipase and esterase activities were low in both barley and wheat extracts. Wheat showed a lipase activity of $0.23 \mu \mathrm{kat}$ per $\mathrm{kg}$ of grain after germination at $20^{\circ} \mathrm{C}$. Barley, which germinated at $6{ }^{\circ} \mathrm{C}$, showed a 30-fold higher $(6.0 \mu \mathrm{kat}$ per $\mathrm{kg}$ of grain) enzyme activity than the wheat extract.

Glycosidases are the predominant enzymes in the extract from germinated barley and wheat. Barley extracts exhibit a higher $\alpha$-amylase, endoglucanase, galactomannase, lipase and peptidase activity, while wheat extracts exhibit higher glycosidase activity ( $\beta$-cellobiosidase, $\beta$-galactosidase, $\beta$-glucosidase and $\beta$-xylosidase).

\section{Hydrolase activity depending on the germination time}

The maximum $\beta$-glucosidase activities are shown in Fig. 1. These maximum activities were achieved at a germination temperature of $7^{\circ} \mathrm{C}$ for barley extracts (duration of 18 days) and $20^{\circ} \mathrm{C}$ for wheat (duration of 7 days).

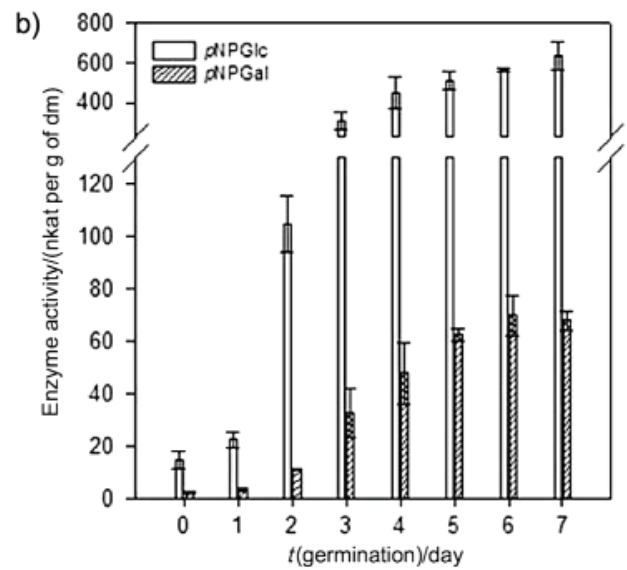

Fig. 1. Hydrolase activities ( $\beta$-glucosidase, $\beta$-galactosidase and lipase) depending on the germination time of: a) barley (pretreatment: $37^{\circ} \mathrm{C}$, imbibition: $4{ }^{\circ} \mathrm{C}$, germination: $7{ }^{\circ} \mathrm{C}$ ) and b) wheat (pretreatment: $-18{ }^{\circ} \mathrm{C}$, imbibition: $25^{\circ} \mathrm{C}$, germination: $20^{\circ} \mathrm{C}$ ). The lipase activity (4-MUL) was lower than the LOQ. Results represent the mean value \pm standard deviation of two independent measurements. dm=dry mass 
The $\beta$-glucosidase activity of barley extracts increased about $150 \%$ to 100 nkat per g of dm during germination for up to eight days. The $\beta$-glucosidase activity of wheat extracts increased 30-fold to about 600 nkat per $\mathrm{g}$ of $\mathrm{dm}$ within four days. The $\beta$-galactosidase activity in barley extracts was constant over the germination time with about 20 nkat per $\mathrm{g}$ of $\mathrm{dm}$, while in wheat grains it increased about 15-fold until day four of the germination. There was also a fivefold increase of lipase activity with a maximum of $(6.6 \pm 0.2)$ nkat per $g$ of $\mathrm{dm}$ in barley extracts after 14 days of germination. Lipase activity could not be detected in the extracts of germinated wheat. These results were used as a basis for the set-up of the design of experiments.

\section{Interaction of hydrolases with the pretreatment, imbibition and germination}

The experiments were carried out under the conditions tested previously, namely $16 \mathrm{~h}$ of imbibition and moisturising of the grains once a day during germination at a maximum temperature of $20^{\circ} \mathrm{C}$. The design of experiments of the hydrolytic enzymes was performed using $p$ NPGlc ( $\beta$-glucosidase), $p$ NPGal ( $\beta$-galactosidase) and 4-MUL (lipase) as substrates. Instead of the $\alpha$-amylase activity, which has already been extensively examined, the three hydrolases ( $\beta$-galactosidase, $\beta$-glucosidase and lipase) showing the highest enzyme activities in the wheat and barley extracts were chosen.

The $\beta$-glucosidases showed the highest activity in both barley and wheat extracts, followed by $\beta$-galactosidase and lipase activity (Table 3; see Table 1 for processing conditions).

The maximum $\beta$-glucosidase activity was up to sixfold higher in wheat $((585 \pm 151)$ nkat per $g$ of $\mathrm{dm})$ than in barley extracts $((109 \pm 15)$ nkat per $\mathrm{g}$ of $\mathrm{dm})$. It was obtained in wheat extracts germinated at $20{ }^{\circ} \mathrm{C}$ (pretreatment: $-18{ }^{\circ} \mathrm{C}$; imbibition: $37^{\circ} \mathrm{C}$ ). A maximum activity in barley extracts pretreated at $50{ }^{\circ} \mathrm{C}$ and subsequently imbibed at $4{ }^{\circ} \mathrm{C}$ was $(109 \pm 15)$ nkat per $\mathrm{g}$ of $\mathrm{dm}$, followed by germination at $6{ }^{\circ} \mathrm{C}$. The $\beta$-galactosidase activity in barley extracts ranged between 22 and 34 nkat per $\mathrm{g}$ of $\mathrm{dm}$. Wheat $\beta$-galactosidase activity had a maximum of $(63 \pm 26)$ nkat per $\mathrm{g}$ of $\mathrm{dm}$ and a minimum of $(7.1 \pm 0.3)$ nkat per $\mathrm{g}$ of $\mathrm{dm}$.

Most of the glycosidase activities ( $p$ NPGal and $p$ NPGlc) in wheat extracts increased with higher germination temperatures within all experiments.

The maximal lipase activity (4-MUL) in barley extracts ranged between 2.3 and 6.7 nkat per $g$ of $\mathrm{dm}$. A germination temperature of $16{ }^{\circ} \mathrm{C}$ led to the highest lipase activity (barley, experiment no. 5: 6.7 nkat per $\mathrm{g}$ of $\mathrm{dm}$ ). The lipase activity in the wheat extract (0.5-4.6 nkat per $g$ of $\mathrm{dm}$ ) was lower than in the extract from barley. In contrast to the glycosidases, wheat grains exhibit lipase activity when germinated at low temperatures, such as $6{ }^{\circ} \mathrm{C}$ (experiment nos. 1 to 4 ), but very low activity at higher temperatures (16 and $20^{\circ} \mathrm{C}$; experiment nos. 5 to 9 ).

The screening of the hydrolytic activities (Table 2) was made first. Based on the results, the hydrolytic activities were examined with a design of experiments (Table 3 ). In order to illustratively show the influence of temper- ature, the $\beta$-glucosidase, $\beta$-galactosidase and lipase activities were compared. The screening experiments in barley extracts were carried out with pretreatment, imbibition and germination temperatures of 37,4 and $7{ }^{\circ} \mathrm{C}$, respectively. The design of experiment no. 4 was used for comparison, so that the pretreatment temperature was different $\left(50\right.$ and $\left.37^{\circ} \mathrm{C}\right)$. Only the $\beta$-galactosidase and lipase activities showed slightly significant differences. The pretreatment, imbibition and germination in the screening experiment of wheat extracts were carried out at temperatures of $-18,25$ and $20^{\circ} \mathrm{C}$, respectively, while experiment no. 6 was used for comparison, also using different imbibition temperatures ( 37 and $25^{\circ} \mathrm{C}$ ). Only the $\beta$-glucosidase activity was slightly, but significantly, different. Other experiments carried out at only one of the three temperatures showed similar results (data not shown). Therefore, no changes or only slight changes were observed with only one variation at one temperature for both comparisons used illustratively. This suggests that not only one temperature, but also the temperatures of at least two parameters have a strong influence on the hydrolase activities.

\section{Calculation of the $\beta$-glucosidase activity}

The $\beta$-glucosidase activity was considered as a marker activity for the calculation of the influence of temperature on the enzyme activity of barley extracts $(p=0.0002$, $\mathrm{R}^{2}=0.899$, adjusted $\left.\mathrm{R}^{2}=0.834\right)$ and wheat extracts $(\mathrm{p}=0.003$, $\mathrm{R}^{2}=0.942$, adjusted $\mathrm{R}^{2}=0.897$ ). The following equations (Eq. 1 for barley and Eq. 2 for wheat extracts) exhibit a three-factor interaction (each regression coefficient was significant), which means that the enzyme yield depends on the cumulative effect of the temperatures from each treatment step.

$$
\begin{gathered}
\text { EA }_{\mathrm{Glc} \text { barley }} / \mathrm{nkat} \text { per } \mathrm{g} \text { of } \mathrm{dm}= \\
=108.919831+0.34389142 \cdot X-1.8766267 \cdot \mathrm{Y}-0.73905377 \cdot \mathrm{Z} \\
-0.00363516 \cdot X \cdot Y-0.01723225 \cdot X \cdot \mathrm{Z}+0.05697475 \cdot \mathrm{Y} \cdot \mathrm{Z} \\
+0.00026216 \cdot X \cdot Y \cdot Z
\end{gathered}
$$$$
\mathrm{EA}_{\mathrm{Glc} \text { wheat }} / \mathrm{nkat} \text { per } \mathrm{g} \text { of } \mathrm{dm}=
$$$$
86.54514-2.85972 \cdot X-3.90868 \cdot Y+23.5278 \cdot Z
$$$$
+0.066558 \cdot X \cdot Y+0.16468 \cdot X \cdot Z+0.20912 \cdot Y \cdot Z
$$$$
-0.00663675 \cdot X \cdot Y \cdot Z
$$

where $\mathrm{EA}_{\mathrm{Glc}}$ is $\beta$-glucosidase activity ( $p$ NPGlc), $X$ is pretreatment temperature $\left({ }^{\circ} \mathrm{C}\right), Y$ is imbibition temperature $\left({ }^{\circ} \mathrm{C}\right)$ and $\mathrm{Z}$ is germination temperature $\left({ }^{\circ} \mathrm{C}\right)$.

The estimated parameters for maximum $\beta$-glucosidase activity of barley extracts were pretreatment at $40{ }^{\circ} \mathrm{C}$ followed by imbibition at $4{ }^{\circ} \mathrm{C}$ and germination at $7{ }^{\circ} \mathrm{C}$, and of wheat extracts at $-18,25$ and $20^{\circ} \mathrm{C}$, respectively. These experiments with the predicted parameters were carried out in order to prove the predictions and were not part of the experiments for the calculation. The $\beta$-glucosidase activity in barley extracts of $(107.9 \pm 4.5)$ nkat per $g$ of $\mathrm{dm}$ verified the predicted value of $106.7 \mathrm{nkat}$ per $\mathrm{g}$ of $\mathrm{dm}$. The observation of $(634 \pm 68)$ nkat per $g$ of $\mathrm{dm}$ also met the prediction (587 nkat per $\mathrm{g}$ of $\mathrm{dm}$ ) of the calculation for the wheat $\beta$-glucosidase. Therefore, the calculation is able to simulate the expected $\beta$-glucosidase activity in the range of the investigated parameters. 
3D surfaces were calculated to visualise the influence of temperature on different treatment steps for $\beta$-glucosidase activity in barley and wheat extracts. The pretreatment temperature in the 3D surfaces was set at $40^{\circ} \mathrm{C}$ (Fig. 2).

The surfaces showed major differences between the temperature influence on $\beta$-glucosidase activity in barley and wheat extracts. The simulation showed that the $\beta$-glucosidase activity in barley extract decreased with the increase of imbibition temperature. At a germination temperature of $6{ }^{\circ} \mathrm{C}$, the $\beta$-glucosidase activity was about 60 $\%$ lower at an imbibition temperature of $40{ }^{\circ} \mathrm{C}$ than at 4 ${ }^{\circ} \mathrm{C}$. With increasing germination temperature from 6 to 20 ${ }^{\circ} \mathrm{C}$, the $\beta$-glucosidase activity increased at an imbibition temperature of $40{ }^{\circ} \mathrm{C}$, but decreased at an imbibition temperature of $4{ }^{\circ} \mathrm{C}$. However, $\beta$-glucosidase activity at a germination temperature of $20{ }^{\circ} \mathrm{C}$ was higher at an imbibition temperature of $4{ }^{\circ} \mathrm{C}$ than at $40{ }^{\circ} \mathrm{C}$. In barley extracts, the combination of a low imbibition temperature followed by a low germination temperature at the border of the experimental set-up led to the highest calculated $\beta$-glucosidase activity.

The influence of imbibition temperature on the $\beta$-glucosidase activity was higher in barley than in wheat extract. By contrast, the germination temperature was the determining factor for wheat $\beta$-glucosidase activity. The $\beta$-glucosidase activity in germinating wheat grains increased more than threefold with the germination temperature. A trend of low imbibition temperature followed
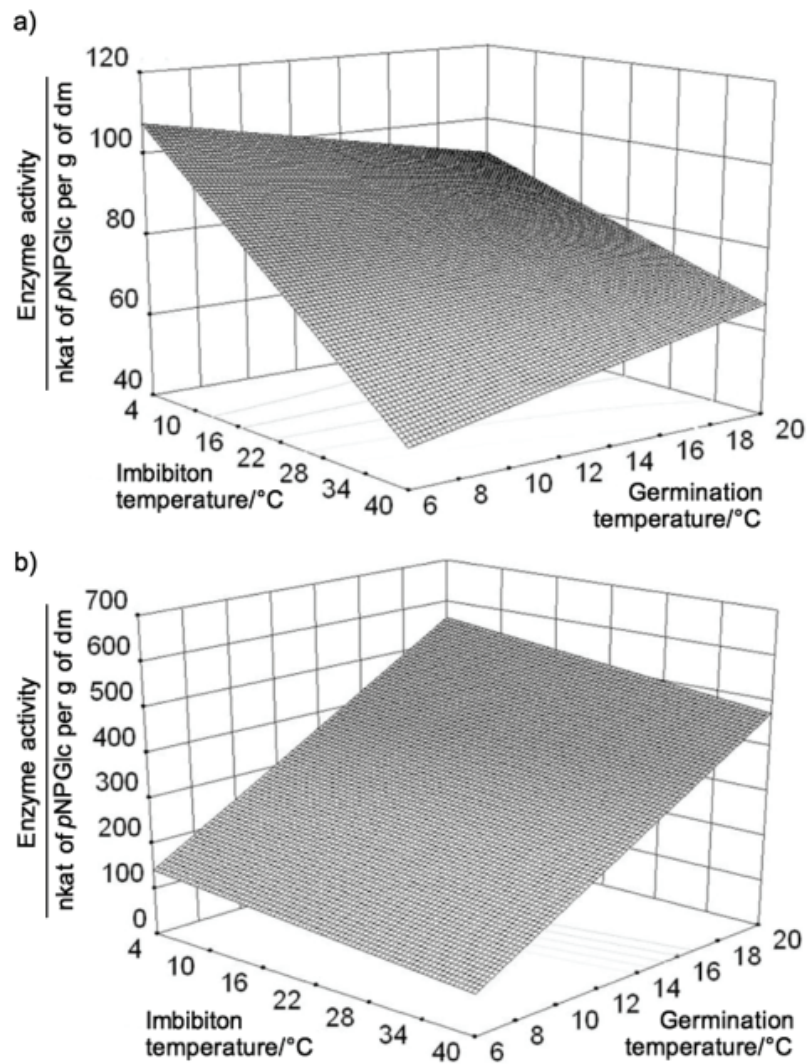

Fig. 2. 3D surfaces of the $\beta$-glucosidase activity from: a) barley and $b$ ) wheat depending on the imbibition and germination temperature with the pretreatment temperature set to $40{ }^{\circ} \mathrm{C}$. $\mathrm{dm}=$ dry mass by high germination temperature can be derived from the $3 \mathrm{D}$ surfaces for high $\beta$-glucosidase activity in wheat extracts.

\section{Discussion}

\section{Comparison of hydrolase activities in the extracts of barley and wheat}

Some hydrolase activities of barley and wheat extracts had been examined previously. The $\alpha$-amylase activity in the barley extract (118 $273 \mu \mathrm{kat}$ per $\mathrm{kg}$ of grain) in this study was higher than the maximum activity (about $5500 \mu \mathrm{kat}$ per $\mathrm{kg}$ of malt, calculated from the original data) measured in eleven barley varieties (24). The $\alpha$-amylase activity in barley extracts in this study was twelvefold higher than in wheat extracts $(10000 \mu \mathrm{kat}$ per $\mathrm{kg}$ of grain). Other authors obtained a maximum $\alpha$-amylase activity of about $38700 \mu \mathrm{kat}$ per $\mathrm{kg}$ (calculated from the original data) in germinated wheat grains for six days, without specifying the unit of mass used for the calculation (25).

The second most abundant enzyme examined in the extracts from germinated barley and wheat was $\beta$-glucosidase. The crude extract of wheat had a more than fourfold higher $\beta$-glucosidase activity ( $400 \mu \mathrm{kat}$ per $\mathrm{kg}$ of grain) than barley (102 $\mu$ kat per $\mathrm{kg}$ of grain). The crude extract from the shoots of germinated wheat had a $\beta$-glucosidase activity of about $1200 \mu \mathrm{kat}$ per $\mathrm{kg}$ of grain (estimation from the original data) in the whole germinated grain (26). The $\beta$-glucosidases from wheat shown in this study had roughly half the specific activities compared with microbial $\beta$-glucosidases from, for example, Lactobacillus brevis SK 3 or Penicillium purpurogenum KJS506 with $700-2000 \mu$ kat per $\mathrm{kg}$ of cell $\mathrm{dm}$, respectively $(27,28)$.

In barley extracts, endoxylanase activity expressed as absorption change ( 1.617 per $\mathrm{h}$ and per $\mathrm{g}$ of $\mathrm{dm}$ at 590 $\mathrm{nm})$, activities of $\alpha$-arabinofuranosidases (2.64 $\mu \mathrm{kat}$ per $\mathrm{kg}$, calculated from original data) and xylosidase (6.27 $\mu \mathrm{kat}$ per $\mathrm{kg}$, calculated from original data) were found (29). Compared to that, barley extracts in this study showed a 33-fold higher endoxylanase absorption change recalculated per $h$ and per $g$ of $\mathrm{dm}$ (53.7) and about the same $\alpha$-arabinofuranosidase activity $(2.2 \mu \mathrm{kat}$ per $\mathrm{kg}$ of grain), whereas the xylosidase activity (1.6 $\mu \mathrm{kat}$ per $\mathrm{kg}$ of grain) was $70 \%$ lower.

The endopeptidase activity expressed as absorption change towards azo-casein per $\mathrm{s}$ and $1 \mathrm{~kg}$ of grain was higher in barley extracts (1.84) than in wheat extracts (0.56). These results were comparable to the values of a previous study with 0.01 absorption change per $h$, although it is not clear which amount of germinated grains was necessary to obtain these results (30).

Most studies concerning cereal lipases are in the context of rancidification of flour during storage (31), therefore, no comparison can be performed with this study.

\section{Influence of the process conditions on the hydrolase activity}

It has been shown that a pretreatment of sunflower seeds, which are orthodox seeds (water to mass ratio $\zeta<0.15$ ), with a temperature of $45{ }^{\circ} \mathrm{C}$ prior to germination 
leads to viability loss (32), thus to reduction of seed germination. This effect is amplified if the grains are exposed to high temperatures in combination with high relative humidity. Wheat grains also showed viability loss in this study when pretreated at $50{ }^{\circ} \mathrm{C}$ (experiments nos. 2 and 4 ), which resulted in lower enzyme activities in comparison with the pretreatment at $-18{ }^{\circ} \mathrm{C}$ (experiments nos. 1 and 3 ). However, the viability loss could only be observed when the grains were germinated at $6{ }^{\circ} \mathrm{C}$. The enzyme extracts germinated at $20^{\circ} \mathrm{C}$ have similar enzyme activities, independent of the pretreatment. Hence, the influence of the germination temperature is most important for the enzyme yield in wheat.

Barley seems to be resistant to high pretreatment temperatures, which could be due to the grain structure. Contrary to wheat grains, barley seeds are encapsulated by husks, which could have this protective effect on the grains.

The imbibition temperature seems to have the highest impact on the enzyme activity in barley extract. The $\beta$-glucosidase activity is almost twofold higher if imbibed at $4{ }^{\circ} \mathrm{C}$ compared to the imbibition at $37^{\circ} \mathrm{C}$ under the same pretreatment and germination conditions. The $\beta$-glucosidase activities after germination at high $\left(20^{\circ} \mathrm{C}\right)$ and low $\left(6^{\circ} \mathrm{C}\right)$ temperatures are comparable considering the standard deviation. Although wheat and barley are closely related (33), there are major differences in the influence of the cereal processing conditions, as shown in this study. As a further step, a response surface methodology should be carried out, as shown for rice previously (34), in order to overcome the limitations of the factorial design (35).

\section{Conclusion}

To the best of our knowledge, the influence of temperature of different cereal treatment steps on the hydrolase activities of barley and wheat grain extracts has so far not been investigated systematically. The calculation of the design of experiments showed, for example, that the maximum activity of $\beta$-glucosidase was reached with low imbibition and low germination temperatures in barley and with low imbibition and high germination temperatures in wheat extracts. However, with only one cultivar of barley and wheat used, more cultivars must be examined in order to check if these results are of general validity. The specific yield of the $\beta$-glucosidase activity in the extracts of barley and wheat grains was up to half of the specific yield of the $\beta$-glucosidase activity in the cultivation of the microorganisms Lactobacillus brevis SK 3 and Penicillium purpurogenum KJS506.

As a proof of principle, $\beta$-glucosidase could be used for food processes, which are of possible interest for consumers who desire 'green labelled' produced foods.

\section{Acknowledgement}

The authors would like to thank Wolfgang Claaßen and Dr. Timo Stressler from the Department of Biotechnology and Enzyme Science of the Institute of Food Science and Biotechnology of the University of Hohenheim for their great support with the germination of the cereal grains and performing preliminary experiments. The au- thors also thank Dr. J. Ackermann \& Co. (Irlbach, Germany) and Deutsche Saatgutveredelung AG (Lippstadt, Germany) for providing barley (Hordeum vulgare L. Grace) and wheat (Triticum aestivum L. Akteur).

\section{References}

1. Fernandes P. Enzymes in food processing: a condensed overview on strategies for better biocatalysts. Enzyme Res. 2010; 2010:ID862537. http://dx.doi.org/10.4061/2010/862537

2. Schäfer T, Borchert TW, Nielsen VS, Skagerlind P, Gibson K, Wenger K, et al. Industrial enzymes. Adv Biochem Engin/ Biotechnol. 2007;105:59-131. http://dx.doi.org/10.1007/10_2006_039

3. Kirk O, Borchert TV, Fuglsang CC. Industrial enzyme applications. Curr Opin Biotechnol. 2002;13:345-51. http://dx.doi.org/10.1016/S0958-1669(02)00328-2

4. Panesar PS, Panesar R, Singh RS, Kennedy JF, Kumar H. Microbial production, immobilization and applications of $\beta$-Dgalactosidase. J Chem Technol Biotechnol. 2006;81:530-43. http://dx.doi.org/10.1002/jctb.1453

5. Zhang L, Guo ZP, Hong JH, Ding ZJ, Gao ZQ, He ZM, Shi GY. Expressing $\beta$-glucosidase from Saccharomycopsis fibuligera in industrial ethanol producing yeast and evaluation of the expressing sufficiency. Ann Microbiol. 2012;62:539-44. http://dx.doi.org/ 10.1007/s13213-011-0289-3

6. Olempska-Beer ZS, Merker RI, Ditto MD, DiNovi MJ. Food-processing enzymes from recombinant microorganisms - a review. Regul Toxicol Pharm. 2006;45:144-58. http://dx.doi.org/10.1016/j.yrtph.2006.05.001

7. Søndergaard HA, Grunert KG, Scholderer J. Consumer attitudes to enzymes in food production. Trends Food Sci Technol. 2005;16:466-74. http://dx.doi.org/10.1016/j.tifs.2005.06.003

8. Hartmann G, Koehler P, Wieser H. Rapid degradation of gliadin peptides toxic for coeliac disease patients by proteases from germinating cereals. J Cereal Sci. 2006;44:368-71. http://dx.doi.org/10.1016/j.jcs.2006.10.002

9. Gänzle MG, Loponen J, Gobbetti M. Proteolysis in sourdough fermentations: mechanisms and potential for improved bread quality. Trends Food Sci Technol. 2008;19:513-21. http://dx.doi.org/10.1016/j.tifs.2008.04.002

10. Poutanen K. Enzymes: an important tool in the improvement of the quality of cereal foods. Trends Food Sci Technol. 1997;8:300-6. http://dx.doi.org/10.1016/S0924-2244(97)01063-7

11. De Palma-Fernandez ER, Gomes E, Da Silva R. Purification and characterization of two $\beta$-glucosidases from the thermophilic fungus Thermoascus aurantiacus. Folia Microbiol (Praha). 2002;47:685-90. http://dx.doi.org/10.1007/BF02818672

12. Code of Federal Regulations 184.1388. Lactase enzyme preparation from Kluyveromyces lactis. Washington, DC, USA: United States Department of Health and Human Services; 2013;21:1.

13. Code of Federal Regulations 184.1387. Lactase enzyme preparation from Candida pseudotropicalis. Washington, DC, USA: United States Department of Health and Human Services; 2013;21:1

14. Dornez E, Gebruers K, Delcour JA, Courtin CM. Grain-associated xylanases: occurrence, variability and implications for cereal processing. Trends Food Sci Technol. 2009;20:495-510. http://dx.doi.org/10.1016/j.tifs.2009.05.004

15. Cereal in malting and brewing. In: Palmer JJ, editor. Cereal science and technology. Aberdeen, UK: Aberdeen University Press; 1989. pp. 147-65. 
16. Teichgräber $\mathrm{P}, \mathrm{Zache} U, \mathrm{Knorr} \mathrm{D}$. Enzymes from germinating seeds - potential applications in food processing. Trends Food Sci Technol. 1993;4:145-9. http://dx.doi.org/10.1016/0924-2244(93)90034-8

17. Osman AM, Coverdale SM, Cole N, Hamilton SE, De Jersey J, Inkerman PA. Characterisation and assessment of the role of barley malt endoproteases during malting and mashing. J Inst Brew. 2002;108:62-7. http://dx.doi.org/10.1002/j.2050-0416.2002.tb00125.x

18. Bryce JH, Goodfellow V, Agu RC, Brosnan JM, Bringhurst TA, Jack FR. Effect of different steeping conditions on endosperm modification and quality of distilling malt. J Inst Brew. 2010;116:125-33. http://dx.doi.org/10.1002/j.2050-0416.2010.tb00408.x

19. Mayolle JE, Lullien-Pellerin V, Corbineau F, Boivin P, Guillard V. Water diffusion and enzyme activities during malting of barley grains: A relationship assessment. J Food Eng. 2012; 109:358-65. http://dx.doi.org/10.1016/j.jfoodeng.2011.11.021

20. Zadoks JC, Chang TT, Konzak CF. A decimal code for the growth stages of cereals. Weed Res. 1974;14:415-21. http://dx.doi.org/10.1111/j.1365-3180.1974.tb01084.x

21. Somogyi M. A reagent for the copper-iodometric determination of very small amounts of sugar. J Biol Chem. 1937;117: 771-6.

22. Nelson N. A photometric adaptation of the Somogyi method for the determination of glucose. J Biol Chem. 1944;153:375-80.

23. Jones BL, Fontanini D, Jarvinen M, Pekkarinen A. Simplified endoproteinase assays using gelatin or azogelatin. Anal Biochem. 1998;263:214-20. http://dx.doi.org/10.1006/abio.1998.2819

24. Acquistucci R, Turfani V, Aureli G. Amylase modification induced by the germination process in organic barley. Eur Food Res Technol. 2011;232:583-90. http://dx.doi.org/10.1007/s00217-011-1423-y

25. Mohamed SA, Al-Malki AL, Kumosani TA. Partial purification and characterization of five $\alpha$-amylases from a wheat local variety (Balady) during germination. Aust J Basic Appl Sci. 2009;3:1740-8.

26. Sue M, Ishihara A, Iwamura $H$. Purification and characterization of a hydroxamic acid glucoside $\beta$-glucosidase from wheat (Triticum aestivum L.) seedlings. Planta. 2000;210:432-8. http://dx.doi.org/10.1007/s004250050029

27. Jeya M, Joo AR, Lee KM, Tiwari MK, Lee KM, Kim SH, Lee JK. Characterization of $\beta$-glucosidase from a strain of Penicillium purpurogenum KJS506. Appl Microbiol Biotechnol. 2010;86:1473-84. http://dx.doi.org/10.1007/s00253-009-2395-8

28. Michlmayr H, Schümann C, Barreira Braz Da Silva NM, Kulbe KD, Del Hierro AM. Isolation and basic characterization of a $\beta$-glucosidase from a strain of Lactobacillus brevis isolated from a malolactic starter culture. J Appl Microbiol. 2010;108:550-59. http://dx.doi.org/10.1111/j.1365-2672.2009.04461.x

29. Debyser W, Derdelinckx G, Delcour JA. Arabinoxylan and arabinoxylan hydrolysing activities in barley malts and worts derived from them. J Cereal Sci. 1997;26:67-74. http://dx.doi.org/10.1006/jcrs.1996.0107

30. Jones BL. Endoproteases of barley and malt. J Cereal Sci. 2005;42:139-56.

http://dx.doi.org/10.1016/j.jcs.2005.03.007

31. Barros M, Fleuri LF, Macedo GA. Seed lipases: sources, applications and properties - a review. Brazil J Chem Eng. 2010;27:15-29. http://dx.doi.org/10.1590/S0104-66322010000100002

32. Bailly C, Benamar A, Corbineau F, Côme D. Changes in malondialdehyde content and in superoxide dismutase, catalase and glutathione reductase activities in sunflower seeds as related to deterioration during accelerated aging. Physiol Plant. 1996;97:104-10. http://dx.doi.org/10.1111/j.1399-3054.1996.tb00485.x

33. Shields R. Pastoral synteny. Nature. 1993;365:297-8. http://dx.doi.org/10.1038/365297a0

34. Capanzana MV, Buckle KA. Optimisation of germination conditions by response surface methodology of a high amylose rice (Oryza sativa) cultivar. LWT-Food Sci Technol. 1997;2:155-63. http://dx.doi.org/10.1006/fstl.1996.0142

35. Atkinson AC, Bailey RA. One hundred years of the design of experiments on and off the pages of Biometrika. Biometrika. 2001;88:53-97. http://dx.doi.org/10.1093/biomet/88.1.53 